\title{
Teacher's Perception of Multiple Intelligence Based on English Teaching for Young Learners
}

\author{
Lidya Ayuni Putri \\ Faculty of Economics and \\ Business \\ Lampung University \\ Lampung, Indonesia \\ lidyaayuniputri@yahoo.com
}

\author{
Rafista Deviyanti \\ Doctoral School of Education \\ University of Szeged \\ Szeged, Hungary \\ rafista.deviyanti@edu.u-szeged.hu
}

\author{
Sri Suningsih \\ Faculty of Economics and \\ Business \\ Lampung University \\ Lampung, Indonesia \\ sri.suningsih@feb.unila.ac.id
}

\begin{abstract}
The multiple Intelligence principle believes that measuring human intelligence using standard IQ assessments on verbal and mathematical skills is not the only way. On the other hand, the theory of multiple intelligence suggests that each individual possesses nine different types of intelligence. Recognizing the different levels of knowledge will aid in determining the variations of students' cognitive styles. As a result, many teachers who recognize the disparities in student performance begin to apply this principle to their learning to increase teaching consistency. This research aims to determine what teachers think about using Multiple Intelligencesbased English language instruction for young learners. Teacher perceptions of multiple intelligence-based English teaching for young EFL students were carried out in several Bandar Lampung elementary schools that used the Multiple Intelligence Theory as a learning framework. Ten teachers were chosen to take part in this interview. This research looked at the teachers' views of using the Multiple Intelligence approach to teach English to students as the suitable method to use in their schools' actual teaching and learning process.
\end{abstract}

Keywords-Teacher Perceptions, Multiple Intelligence, Young Learners, English as a Foreign Language

\section{INTRODUCTION}

One of the things that distinguish humans from other living things is intelligence. Humans have much higher intelligence than other living creatures. With this intelligence, humans can rule the world and establish civilization. Human intelligence can develop in line with human interaction with nature. In other words, humans can learn and increase their intellectual potential.

The intelligence possessed by humans is not only on one side, but many bits of intelligence will be improved for their survival. Intelligence must be balanced so that achieving life goals can be done as well as possible. Intelligence in arranging words both orally and in writing is intelligence in language. Someone who can work such as writing, poetry, and reading well is one of his language intelligence.

Likewise in dealing with something that involves thinking deeply. Someone who has mathematical/logical intelligence will be able to solve problems well because of his high analytical skills. Thinking skills and language skills are intelligence that is acquired through education. Education that processes humans for the better to increase the potential that exists within them. Therefore, in this case, Multiple Intelligence will be discussed through education to help improve the intelligence of the students.

The multiple intelligence (MI) approach to education focuses on a student-centered learning model in which all teaching and learning processes are customized and modified to meet students' learning needs [1]. All students are equally valuable in terms of having the opportunity to fully develop their different intellectual abilities. They will achieve success in their lives based on their expertise in their field [1-4].

Teachers play an important role in learning activities in using multiple intelligence systems. They must facilitate and be stakeholders to educate students. On that account, the knowledge and beliefs of the teachers contribute a lot to the classroom. What teachers implement and do in the class reflects what they believe. In addition, [5] stated teacher knowledge and belief provide a framework and schema that underlies teacher actions in the classroom. Thus, the beliefs of teachers studied in this study are related to their beliefs in teaching multiple intelligence-based English to students in the classroom.

Woods views teachers' beliefs, assumptions, and knowledge as essential factors that influence their decision-making process while planning and making learning decisions. This premise is supported by [6], who claim that belief serves as a fundamental direction for people's ideas and behaviors. Furthermore, according to [7], teacher views can have a significant 
impact on what teachers do and, as a result, the learning possibilities that students have.

\section{LITERATURE REVIEW}

\section{A. Definition of Perception}

Belief is regarded as a psychologically held understanding, premise, or proposition about the world that is assumed to be true [8]. In addition, [9] stated that the relationship between teacher beliefs and learning practices is increasingly attracting the attention of educational researchers. In [10], it is stated that beliefs affect teacher practice which also influences the actions during class activities. Therefore, teachers behave according to the beliefs they have.

In the teaching-learning process, teacher beliefs are the basic model in planning and decision-making. Reference [11] recommended the concept of belief, assumption, and knowledge (BAK) as a description of the decision-making process. Woods views teachers' beliefs, assumptions, and knowledge as essential factors that influence their decision-making process while planning and making learning decisions. This premise is supported by [6], who claim that belief serves as a fundamental direction for people's ideas and behaviors. Furthermore, according to [7], teacher views can have a significant impact on what teachers do and, as a result, the learning possibilities that students have.

\section{B. Definition of Multiple Intelligence}

Intelligence according to the meaning of language is understanding, speed, and perfection of something, in the sense of ability, and in understanding something quickly and perfectly. At first, intelligence was only related to the ability of the structure of reason (intellect) in capturing the symptoms of something, so that intelligence was only in contact with cognitive aspects. However, in subsequent developments, it is realized that human life is not merely fulfilling the structure of reason, but there is a heart structure that needs to have its place to grow affective aspects, such as emotional, moral, spiritual, and religious life. Therefore, the types of intelligence in a person are very diverse along with the abilities or potentials that exist in him.

Intelligence means perfect development of his mind, clever and sharp mind. Besides being intelligent, it can also mean perfect body growth such as being healthy and physically strong. Furthermore, another opinion says that intelligence is the ability to solve problems or produce something that is needed in a certain cultural setting. The range of problems or something that is produced starts from the simple to the complex. A person is said to be intelligent if he can solve the problems faced in his life and can produce results something valuable/useful for mankind.

Meanwhile, according to [12], intelligence is the ability to solve problems, or to create products, which are valued in one or more cultures. Intelligence is often defined as the ability to adapt to the environment or learn from experience. Humans live and interact in a complex environment. Humans must learn from the experience for the sake of their survival. Humans who learn often face new situations and problems. It requires the ability of individuals who learn to adapt and solve any problems encountered.

In the concept of Multiple Intelligence, individual differences of students are accepted and served with a grounded belief as stated by Howard Gardner that "we are all so different because, in essence, we have different combinations of intelligence". If this is realized, at least it has a better chance of being able to properly address the various problems faced in life in the world. The application of Multiple Intelligence in education will cause educators to be wiser and able to appreciate and facilitate the development of their students.

\section{Nine Kinds of Multiple Intelligence}

At first, seven kinds of multiple intelligence areas were introduced by Gardner which are associated with a specific area of the brain. Later, he added the eighth and ninth intelligence and continued to research the possibilities of other intelligence. Gardner describes nine kinds of intelligence as follows:

- Linguistic intelligence refers to sensitivity to spoken and written language, as well as the capacity to study and use language to achieve specific objectives.

- Logical-Mathematical Intelligence refers to the capacity to rationally examine situations, execute mathematical operations, and conduct scientific investigations.

- Musical intelligence refers to abilities in musical pattern recognition, composition, and performance.

- Spatial intelligence refers to the ability to perceive and control large geographical patterns as well as more constrained regional patterns.

- Bodily-Kinesthetic Intelligence refers to the ability to solve issues or develop things using one's entire body or sections of one's body.

- Naturalistic Intelligence is the ability to recognize and classify a variety of species (plants and animals) in their surroundings. This intelligence is linked to the ability to think about and comprehends natural phenomena. It is the capacity to identify and classify plants, animals, and other characteristics of your surroundings.

- Interpersonal Intelligence refers to a person's capacity to comprehend the goals, motives, and desires of others, as well as their ability to collaborate effectively with others.

- Intrapersonal intelligence is the ability to comprehend oneself, to develop an effective 
working model of oneself (including one's wants, anxieties, and talents), and to effectively manage one's own life using that information.

- Existential intelligence, or the ability to ponder about cosmic and existential concerns such as the advertising function of our existence in the cosmos, as well as the nature of life, death, happiness, and tragedy.

\section{Multiple Intelligence in the Context of Education}

The theory of intelligence was first introduced in the phycology field which then attracted educators' interest. As Multiple Intelligence theory (MI) becomes a new groundbreaking approach to help students learn through their strengths, they can enhance and develop their skills and activities to overcome difficulties at school and in the classroom. Furthermore, this intelligent paradigm is expanded not only based on test results but also based on the ability of students to learn in diverse ways.

The Multiple Intelligence theory is important in teaching English for young learners, especially for teachers. Through multiple intelligence, teachers will be able to map the children's strengths in the teaching and learning process. Teachers can also help students to develop their strengths and understand the lessons. Consequently, multiple intelligence can help teachers identify students' learning styles through their dominant intelligence. Students will be able to understand the lesson easily when they develop their intelligence as a door to learning material.

In sum, multiple intelligence-based English teaching believes that everyone is smart. Students will know what they can expect for themselves then their achievement can be improved as measured by both standardized and informal tests. Hopefully, Multiple Intelligence-based instructions can be the key to experience success as students grow up in various ways.

\section{E. English Teaching for Young Learners}

Nowadays, learning a foreign language has become a part of our daily life. Children have started learning English as a foreign language at an early level. Reference [13] stated that "Children can always do more than we think they can; they have great learning potential, and foreign language classes are detrimental to them if we don't take advantage of that potential." Thus, language learning is good for children in both the first and second stages.

Teaching English to children is different compared to teaching English to adult learners. The teachers need to consider the techniques, strategies, activities, motivation, and also children's background knowledge. Some children may feel unenthusiastic because they cannot keep their motivation when doing a difficult task which may result in losing motivation quickly.

Teachers require young learners to carefully control the language to be taught and the classroom activities to be carried out for them, which is a huge distinction. Reference [14] claims that young learners have different physical and psychological demands than adolescents or adults, thus teachers must plan for engaging learning. They must also pay close attention to satisfying the needs of pupils since this is believed to encourage youngsters to pay greater attention to their learning.

\section{RESEARCH METHOD}

This used descriptive qualitative research method. In collecting the data, the researchers used an intelligence survey and also semi-structured interviews. These techniques were used to seek the teachers' perception in implementing Multiple Intelligence in Elementary Schools in Bandar Lampung, Indonesia. The interview was used to obtain in-depth data and confirm the teachers' answers to the questionnaire. 10 experienced English teachers participated in this research. These teachers had more than 4 years of teaching English to young learners. Therefore, the teachers are assumed to be capable of teaching English to young learners. To obtain the teachers' perception of Multiple Intelligence, the participating teachers were interviewed. The semi-structured interview was developed and used. During the interviews, there was a list of questions and subjects that were to be covered in a specific order. The interviewer followed the instructions, although variations were allowed when they were necessary. There were two components to the interview guide. The first component of the survey asked about the age, gender, educational level, and experience of the teachers. The other half dealt with several topics directly linked to the study, such as teachers' perception of the MI theory. In analyzing the data, the researchers adapted 3 steps, namely: organizing and familiarizing, coding and reducing, and interpreting and familiarizing.

\section{FINDING AND DISCUSSION}

\section{A. The Results of Oral Interview}

The participants in this study were initially interviewed to acquire their personal information. Then they were questioned whether or not they had heard of the MI theory. The teachers who answered questions indicating their familiarity with the MI theory were then questioned to confirm their understanding of the theory.

The MI theory was viewed positively by the majority of the participants. They claimed that identifying each student's level of intelligence would make communication and interaction between instructor and students simpler. Students will like their lessons, which will lead to their acting satisfactorily in activities that are tailored to their intelligence. On the other hand, some teachers believed in general intelligence rather than Gardner's definition. These teachers thought that certain pupils learn faster than others, regardless of the form of education used. 
About half of the instructors agreed that the MI theory could be implemented in schools, but that it would require additional resources, time, and energy. It may also be encouraging in this sense. The other half, on the other hand, thought it was not suitable for language lessons and saw it as a gap between theory and practice. Teachers also mentioned some challenging items that can make multiple intelligence difficult to be implemented in the classroom such as the lack of facilities, lack of MI-based textbooks, lack of time and time management problems, and lack of training and motivation for teachers.

Some teachers said that linguistic intelligence is the most crucial intelligence in foreign language learning. The belief that linguistic intelligence encompasses all talents in language acquisition and governs the entire language learning process was the fundamental basis for their selection. According to this group, students with dominant linguistic intelligence are strong language learners who can quickly retain words and manipulate and paraphrase complicated structures. Linguistic intelligence should be regularly stimulated in foreign language learning circumstances through discussions, word games, storytelling, and other similar activities to be effective at the four skills required in language acquisition. However, as previously stated, the vast majority of participants believed in the usage of intelligence other than language intellect.

\section{B. Discussion}

According to current Multiple Intelligence theories, all intelligence types must interact and collaborate to some extent $[15,16]$. In line with that, [17] states that no intelligence exists by itself in life. They are always interacting with one another.

Interestingly, all the participants agree that linguistic intelligence is not the only intelligence that is responsible for language learning. Most of the participants also believe that musical intelligence plays an important role in learning a foreign language, especially for children. This is in line with [18] who state that there is more to language than what is usually subsumed under the rubric of linguistics. There are aspects of language such as rhythm, tone, volume, and pitch that are more closely linked to a theory of music rather than to a theory of linguistics.

According to [19], Multiple intelligences theory gives a wide map of the software of the mind that is consistent with cognitive science and general intelligence. Following this, the study's findings revealed that instructors feel multiple intelligences have a positive impact on the teaching-learning process. Furthermore, reference [20] claimed that pupils with multiple intelligences learn more successfully.
The findings of this research revealed teachers' preference not to focus on one kind of intelligence. They agree that as the persons who are responsible in the class, they have to accommodate all kinds of intelligence in the learning process. Types of Multiple intelligence that are often used in a certain field should be evaluated to see if they fit or mismatch with the prevailing intellect types of the learners. It is also worth noting that a MI discipline profile might change over time. "Disciplines themselves evolve, settings change, and demands on persons who have acquired early competence,"[21]. Over the coming decades, it will be necessary to continue to educate oneself and others." As a result, Multiple Intelligence discipline profiles may evolve in the same manner that an individual's Multiple Intelligence profile evolves. Scholars, researchers, and practitioners should examine Multiple Intelligence discipline profiles regularly.

\section{CONCLUSION}

Accepting Multiple Intelligence theories proposed by Gardner means there is a shift from the traditional educational system. In the past, the learning process in the class occurs without considering the student's multiple intelligences. These theories allow the students to explore the learning process according to their ability. It also helps the young EFL learners to learn the lessons more effectively. Teachers can employ integrated tactics and instructional activities to adapt to the diverse requirements of pupils in terms of intelligence profiles, learning styles, and learning preferences, thanks to the Multiple Intelligences Theory." Furthermore, "knowledge of the many bits of intelligence and teaching tactics might increase learning motivation and boost memory in the process of learning acceleration".

\section{REFERENCES}

[1] T. R. Hoerr. Becoming A Multiple Intelligences School. Virginia, USA: ASCD (Association for Supervision and Curriculum Development). 2000.

[2] J. Harmer. The Practice of English Language Teaching (4th ed). Essex, UK: Pearson Education. 2007.

[3] M. Chatib. Sekolahnya manusia. Bandung: Angkasa. 2013

[4] Armstrong, T. "Multiple intelligences in the classroom (3rd Ed)". Virginia, USA: ASCD (Association for Supervision and Curriculum Development). 2009.

[5] J. Richards, and C. Lockhart. Reflective teaching in second language classrooms. New York: Cambridge University Press. 1996

[6] E. Fauziati. Teaching English as a foreign language: Principle and practice. Surakarta: Era Pustaka Utama. 2015.

[7] S. Borg, \& S. Al-Busaidi. Teachers' Beliefs and Practice Regarding Learning Autonomy. ELT Journal Vol. 66. 2012. 283-292.

[8] B.K Hofer, and P.R. Pintrich. The development of Epistemological Theories: Beliefs about Knowledge and Knowing and their relation to learning. Review of Educational Research 67 (1), 1997. 88-140.

[9] L. Canh, \& R. Barnard, A survey of Vietnamese EAP teacher's beliefs about grammar teaching. In Zhang, L.J., \& Rubdy, R., 
\& Alsagoff, L. (eds.). Englishes and Literatures in English in a Globalised World: Proceedings of the 13th International Conference on English in Southeast Asia, 2009. 246- 259. Singapore: National Institute of Education, Nanyang Technological University.

[10] K. Bingimlas, \& M. Hanrahan. "The relationship between teachers' beliefs and their practice: How the literature can inform science education reformers and researchers". In M.F. Tasar \& G. Gakamkci (Eds.). Contemporary Science Education Research: International Perspectives. Ankara, Turkey: Pegem Akademi. 2010, (pp. 415-422).

[11] D. Woods. Teacher Cognition in Language Teaching. Cambridge: Cambridge University Press. 1996.

[12] H. Gardner. Intelligence Reframed: Multiple Intelligences for the 21st Century. New York, NY: Basic Books. 1999.

[13] C. T. Linse. Practical English Language Teaching: Young Learners. New York: McGraw-Hill Companies, Inc. 2005.

[14] L. Cameron. Teaching languages to young learners. Cambridge: Cambridge University Press. 2001.

[15] S. Moran, M. Kornhaber, \& H. Gardner. Orchestrating multiple intelligences. Educational Leadership, 64(1), 2006. 22-27.
[16] P. Torresan. Intelligences and styles in language teaching: What is the difference? Didáctica (Lengua y Literatura), 9, 2007. 315-325.

[17] M. A. Christison. Applying, multiple intelligences theory: In pre-service and in-service TEFL education programs. Forum, 36(2). 1998

[18] J. C., Richards, \& T. Rodgers. Approaches and methods in language teaching. Cambridge: Cambridge University Press. 2001 .

[19] S. Branton. Multiple intelligence in teaching education: Lessons learned from neuroscience. Journal of Intelligence, 6(3). 2018. p 38.

[20] Z. K. Dolati, \& A. Tahriri. EFL Teachers' Multiple Intelligences and Their Classroom Practice. SAGE. 2017. (112) Doi: $10.1177 / 2158244017722582$

[21] H. Gardner. The five minds for the future. The School Administrator, 66(2), 2009. 16-20. 